\title{
Coagulase-negative staphylococci in ewe udder surface and raw milk samples
}

\author{
Andualem Tonamo ${ }^{1,2}$ - István Komlósi ${ }^{2}$ - Flóra Mária Petróczki ${ }^{1,3}$ - Ferenc Peles ${ }^{3}$ \\ ${ }^{1}$ Doctoral School of Animal Husbandry, University of Debrecen, Böszörményi Street 138, 4032 Debrecen, Hungary \\ ${ }^{2}$ Institute of Animal Science, Biotechnology and Nature Conservation, Faculty of Agricultural and Food Sciences and Environmental \\ Management, University of Debrecen, Böszörményi Street 138, 4032 Debrecen, Hungary \\ ${ }^{3}$ Institute of Food Science, Faculty of Agricultural and Food Sciences and Environmental Management, University of Debrecen, \\ Böszörményi Street 138, 4032 Debrecen, Hungary \\ andytonamo@agr.unideb.hu
}

\begin{abstract}
SUMMARY
Coagulase-negative staphylococci (CNS) are among the major causes of subclinical mastitis in dairy ewe flocks. This has a financially significant impact on the ewe dairy sector and consumer health. The determination of the bacterial count, particularly CNS, is critical in terms of the quantity and quality of ovine milk. Thus, the purpose of this study was to quantify the CNS count in the udder surface and raw milk samples of the ewe, in addition, to identify CNS strains $(n=8)$ collected from udder surface and individual raw milk samples by $16 S \mathrm{r} R N A$ gene sequencing. A total of 164 samples of udder surface and raw milk originated from four sheep farms were tested. The obtained values were compared between the different farms. Furthermore, values during 2018 and 2019 in the case of Farm I were compared. Significantly higher $(p<0.05)$ average count was observed in udder surface samples taken from Farm I $\left(2.8 \pm 1.0 \mathrm{lg} C F U / \mathrm{cm}^{2}\right)$ than that of Farm III samples (2.3 \pm 0.6 $\left.\lg C F U / \mathrm{cm}^{2}\right)$. In the case of individual raw milk, the higher value was observed in samples derived from Farm III ( $\left.3.5 \pm 0.9 \lg \mathrm{CFU} / \mathrm{mL}\right)$, while the obtained value was significantly lower ( $p<0.05)$ in samples originated from Farm IV $(1.8 \pm 0.4 \lg C F U / m L)$. In the bulk tank milk samples, the highest mean value was $5.3 \pm 0.4 \mathrm{CFU} / \mathrm{mL}$, and there was no significant ( $p>0.05)$ variation between farms. Coagulase-negative staphylococci counts were decreased to a certain extent in both sample types tested during 2019 except for individual raw milk derived from the Tsigai breed. The correlation between the mean CNS counts of udder surface and individual raw milk was very weak $(r=0.048)$. Staphylococcus simulans, Staphylococcus auricularis, and Staphylococcus equorum were identified by molecular sequencing and Staphylococcus simulans were the most frequently identified CNS species. A higher CNS count of bulk tank milk than individual raw milk indicates possible contamination during milking and storage. Therefore, further studies are required to investigate the other sources of bulk tank milk contamination to improve the hygienic quality of milk.
\end{abstract}

Keywords: Coagulase-negative staphylococci; individual raw milk; udder surface

\section{INTRODUCTION}

Based on their ability to produce coagulase enzymes, staphylococcal bacteria are categorized as coagulase-positive (e.g. S. aureus, S. hyicus, and S. delphini) and coagulase-negative (e.g. S. haemolyticus $S$. simulans, and $S$. epidermidis) (Vasileiou et al., 2019). Consumption of ewe milk contaminated with coagulase-negative staphylococci (CNS) can causes health problems in humans, particularly milk products made from unpasteurized raw milk (Zell et al., 2008; Kadariya et al., 2014). Some CNS strains produce heat resistant enterotoxins that cause food poisoning. However, CNS strains had a lower level of enterotoxigenicity and pathogenicity in comparison to Staphylococcus aureus, which is coagulase-positive (Ünal and Çinar, 2012; Podkowik et al., 2013). Like $S$. aureus, enterotoxins were detected in CNS strains such as S. epidermidis, S. cohnii, S. haemolyticus, and $S$. xylosus from ovine milk and cheese samples (Podkowik et al., 2013). Many studies have shown that CNS can enter into milk from the udder and teat surfaces of animals as well as from the milker's hand (Bergonier and Berthelot, 2003; Mavrogianni et al., 2007; Vasileiou et al., 2019). These bacteria are associated with subclinical mastitis in dairy ewe flocks (Spanu et al., 2011; Gelasakis et al., 2015). The prevalence of subclinical mastitis in dairy ewe flocks is usually between 5 and $30 \%$ or higher (Contreras et al., 2007; Vasileiou et al., 2018).

According to the study from Greece, the overall prevalence of CNS in subclinical mastitis ewe milk was $59.7 \%$ with the S. chromogenes $(23 \%)$ predominant species followed by $S$. epidermidis (19.8\%), $S$. simulans (17.6\%), and S. hominis (8.8\%) (Vasileiou et al., 2018). European Union legislation No. 2073/2005 on foods of animal origin (European Commission, 2005) sets the limit value for $S$. aureus (coagulasepositive staphylococci). On the other hand, the limit value for CNS has not been established. To improve milk hygiene in dairy ewe flocks, it is crucial to know the milk's CNS count and the source of contamination. However, in the studied area, the data on CNS count in the milk and udder surface of the ewe were very scarce. Therefore, this study aimed to examine coagulasenegative staphylococci in the udder surface and raw milk samples from the ovine. Furthermore, to identify CNS strains $(n=8)$ collected from udder surface and individual raw milk samples by $16 \mathrm{~S}$ rRNA gene sequencing.

\section{MATERIALS AND METHODS}

One hundred fifty-four samples were obtained from four sheep farms. Of these, 77-77 samples were taken from the udder surface (US) and individual raw milk (IRM). Moreover, 10 bulk tank milk (BTM) samples 
were collected from farms where ewes were milked. Animals were not milked on Farm I during this study, an experimental sheep farm. However, the installation of a milking parlour was done, and milking is expected in the coming years. The flock on the Farm I consists of Merino, Tsigai, and Dorper breeds, while Lacaune in Farm II and Farm III, and British Milksheep in Farm IV. During March-July 2018 and 2019, the samples were collected from Hajdú-Bihar (Farm I-Farm III) and Jász-Nagykun-Szolnok (Farm IV) Counties of eastern Hungary.

Farm characteristics, date of sample collection, sample collection procedures, and sample handling have been described in our previous publication (Tonamo et al., 2020). Bacteria were cultured on BairdParker agar (Biolab Ltd., Hungary) enriched with egg yolk and tellurite by spreading $0.1 \mathrm{~mL}$ of dilution. After 48 hours of incubation at $37{ }^{\circ} \mathrm{C}$, the colonies were counted.

Eight CNS strains collected from 12 samples (6 US and 6 IRM) obtained from Farm I were identified by partial 16S rRNA gene sequencing. The sequencing was done in the Biomi Ltd. Company, Hungary. The sequencing of the partial $16 \mathrm{~S}$ rRNA gene was with 519R and 27F primers (Lane, 1991), used in the amplification. Two databases with a partial doublestranded 16S rRNA gene fragment were used as a reference. The National Center for Biotechnology Information and the TrueBacTM ID (DB ver.
20190409) (Yoon et al., 2017) databases. The Basic Local Alignment Search Tool algorithm was used to carry out alignment and the alignment is limited to cultivable strains.

GraphPad Prism 3.02 and Microsoft Excel 2016 were used to analyze data. The US sample's CNS count was divided by 20 , as the sample was obtained from a surface area of $20 \mathrm{~cm}^{2}$. Then the results were transformed into a logarithm. Farm (Farm I-Farm IV) and year (Farm I) effect on CNS count were evaluated. The mean difference was compared using a one-way analysis of variance and the Kruskal-Wallis test. The correlation between the US and the corresponding individual result of the raw milk sample was determined by Pearson correlation. The significance level was considered at $\mathrm{p}<0.05$.

\section{RESULTS AND DISCUSSION}

The mean values of coagulase-negative staphylococci (CNS) in udder surface (US) samples originated from four sheep farms were shown in Figure 1. The average count in udder surface samples obtained from Farm I, II, III, and IV was $2.8 \pm 1.0,2.5 \pm 0.8$, $2.3 \pm 0.6$, and $2.4 \pm 0.6 \mathrm{lg} \mathrm{CFU} / \mathrm{cm}^{2}$, respectively (Figure 1). The mean value of US samples derived from Farm I was significantly $(\mathrm{p}<0.05)$ higher than that of Farm III samples (Figure 1).

Figure 1. Coagulase-negative staphylococci count in ovine udder surface

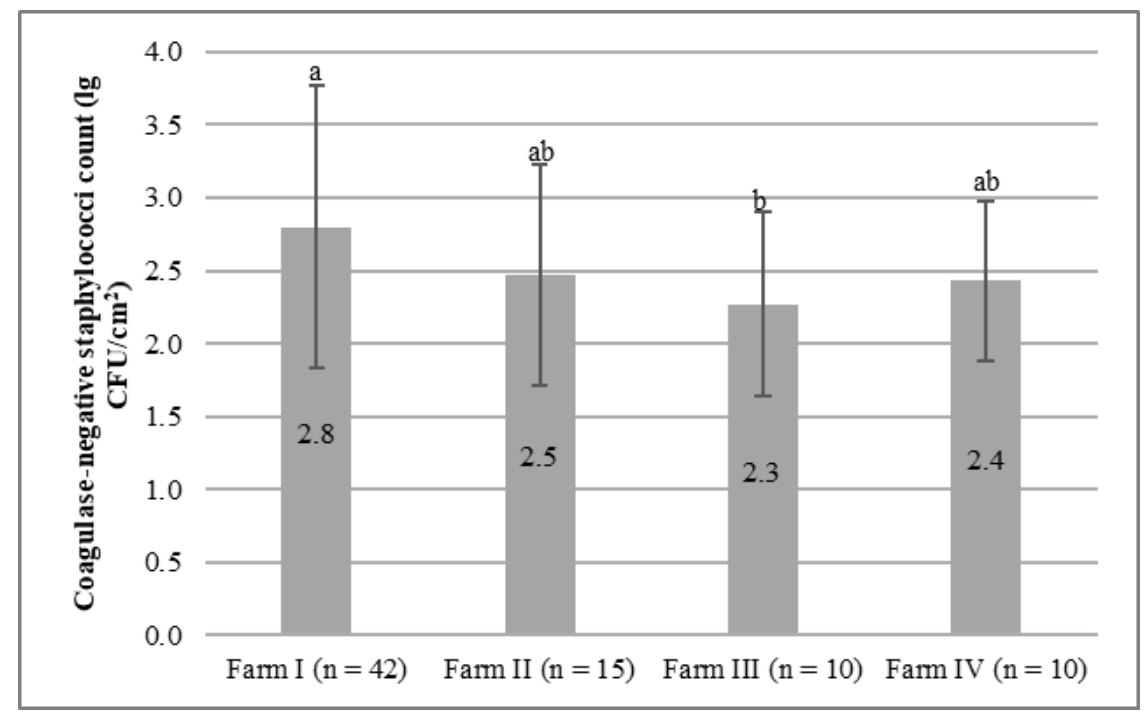

The mean of individual raw milk (IRM) samples derived from Farm I, II, III, and IV was $3.2 \pm 1.1$, $3.3 \pm 1.0,3.5 \pm 0.9$, and $1.8 \pm 0.4 \mathrm{lg} \mathrm{CFU} / \mathrm{mL}$, respectively (Figure 2). The value of IRM samples from Farm IV was substantially $(\mathrm{p}<0.05)$ lower value than that originating from other farm samples (Figure 2). This may be attributed to the British Milksheep breed on
Farm IV, which is one of the strong and hardy sheep breeds. This ewe breed can withstand bacteria invading the mammary gland via the teat canal. Similar to our results, another study from Kosovo revealed that the farm had a substantial impact on the total bacterial count of individual raw ewe milk (Bytyqi et al., 2013). 
Figure 2. Coagulase-negative staphylococci count in ovine individual raw milk

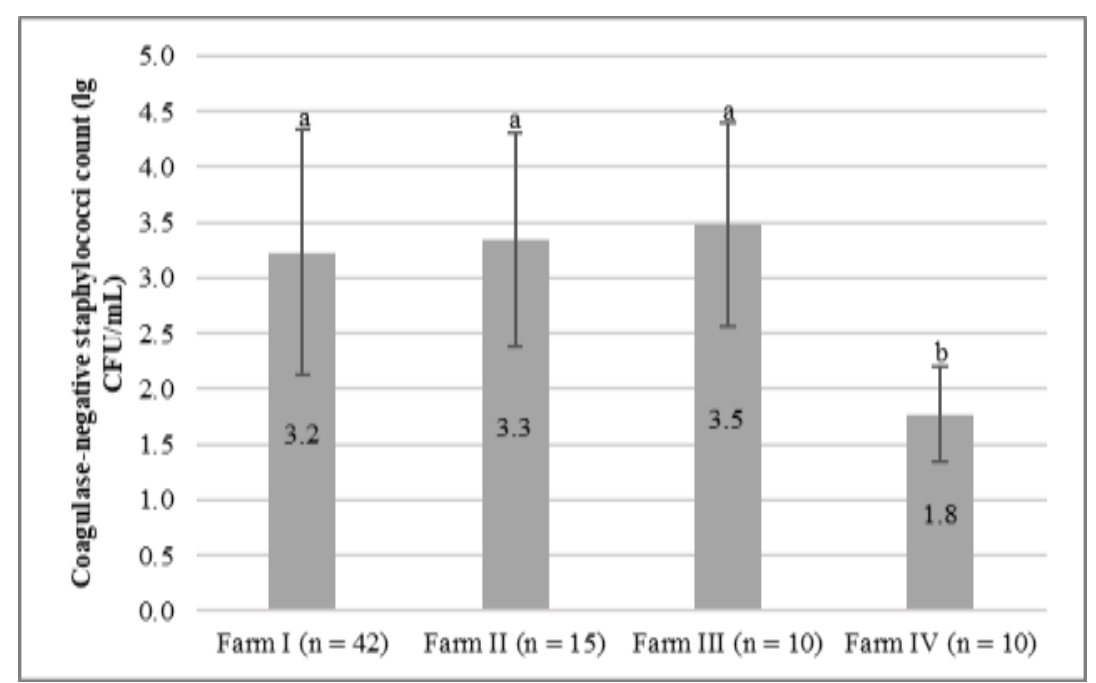

The average value of BTM samples in Farm II, III, and IV was $5.3 \pm 0.4,4.3 \pm 0.4$, and $4.3 \mathrm{lg} \mathrm{CFU} / \mathrm{mL}$, respectively (Figure 3). Only one BTM sample in Farm IV was examined for the bacterial count. Therefore, the result of Farm IV was not statistically compared to the results of other farms. Indeed, there is no significant ( $p>0.05)$ difference between Farm II and III. However, the average value of BTM from Farm II is slightly higher (Figure 3). A higher CNS count of BTM than IRM indicates possible contamination during milking and storage. Comparatively similar staphylococci mean count $(4.4 \pm 0.5 \mathrm{lg}$ CFU/mL) was reported from Spain for a bulk tank ewe's milk samples (Poveda et al., 2020).

Figure 3. Coagulase-negative staphylococci count in ovine bulk tank milk

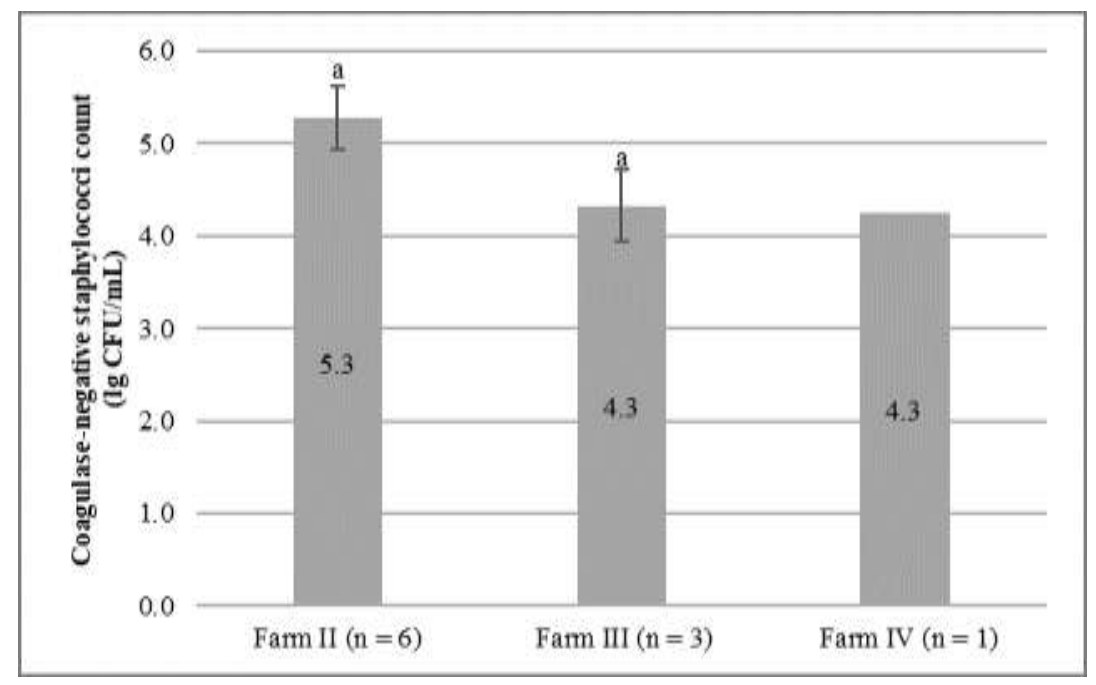

The mean was statistically compared between the year of investigation (2018 and 2019) for Merino, Tsigai, and Dorper ewe breeds on Farm I (Figure 4). The CNS count of all breeds was significantly $(\mathrm{p}<0.05)$ lower in US samples tested during 2019 than in 2018. Unlike US samples, a non-significant $(\mathrm{p}>0.05)$ difference was observed in IRM samples taken from three ewe breeds between 2018 and 2019. The variation of mean value between years could be explained as a difference in management practices every year. There might be an improvement in the hygienic conditions of sheep farms over time. Similarly, differences in the total bacterial count in ewe BTM have been observed between years in Spain (Gonzalo et al., 2010). The mean of the US and the corresponding IRM results were used to measure the coefficient of correlation. There was none significant $(\mathrm{p}>0.05)$ positive correlation coefficient $(\mathrm{r}=0.048)$ between $\mathrm{CNS}$ counts of US and IRM. This shows that the correlation between CNS counts of US and IRM is very weak. 
Figure 4. The effect of year of investigation on CNS count of udder surface (lg CFU/cm²) and individual raw milk (lg CFU/mL) samples of three ewe breeds on Farm I

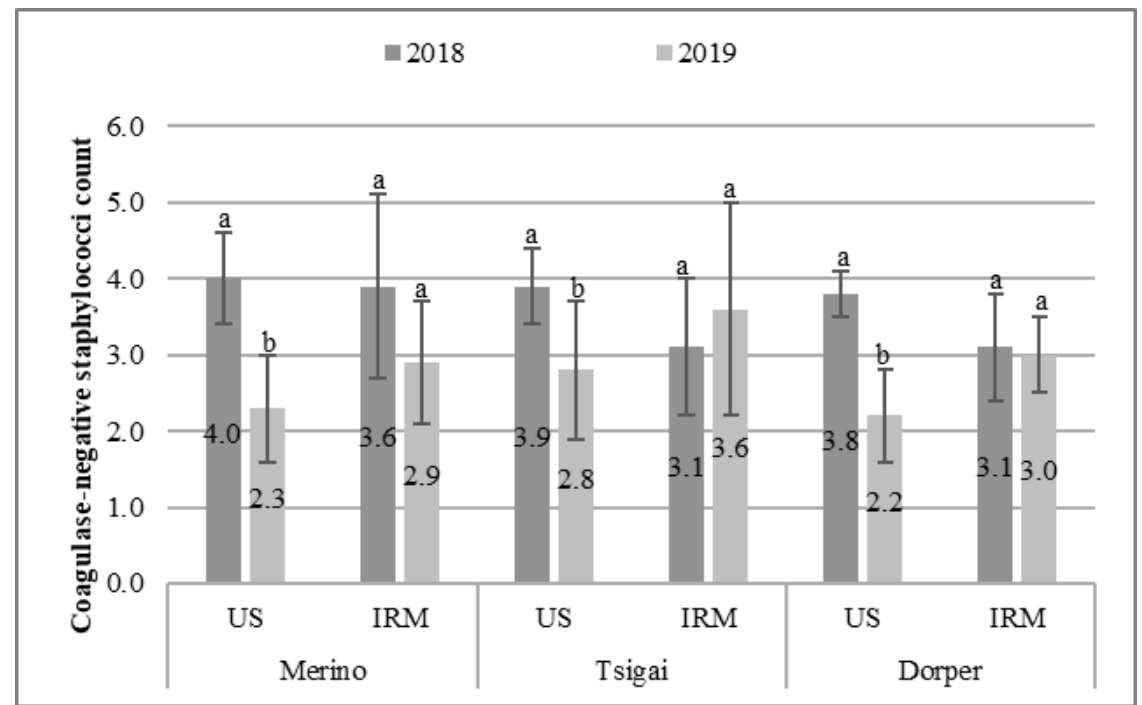

During 2018 and 2019, 6 udder surface and 6 individual raw milk samples were examined for all breeds, but in the case of Tsigai breed in 2018, 12-12 udder surface and individual raw milk samples were examined. US: udder surface, IRM: individual raw milk.

Eight CNS isolates were successfully identified using sequencing analysis (Table 1). In this study, three CNS species were identified from US and IRM samples. The most frequently identified species was $S$. simulans $(37.5 \%)$ followed by $S$. auricularis $(25 \%)$, and S. equorum (25\%) (Table 1). Similarly, from
Brazil, Martins et al. (2017) reported S. simulans was the most frequent isolate in both ewes with subclinical mastitis and in healthy ewes. On the contrary, the finding by Onni et al. (2010) from Italy revealed that $S$. epidermidis was the most isolated CNS species in ovine milk by molecular analysis.

Table 1. Frequency of coagulase-negative staphylococci isolates identified by 16S rRNA sequencing

\begin{tabular}{ccc}
\hline Sources & Species & Frequency n (\%) \\
\hline Individual raw milk & Staphylococcus simulans & $3(37.5)$ \\
Individual raw milk & Staphylococcus auricularis & $2(25)$ \\
Individual raw milk & Staphylococcus equorum & $1(12.5)$ \\
Udder surface & Staphylococcus equorum & $2(25)$ \\
\hline & Total & $\mathbf{8 ( 1 0 0 )}$ \\
\hline
\end{tabular}

\section{CONCLUSIONS}

The mean of coagulase-negative staphylococci count was low in the udder surface and individual raw milk samples. There was a very weak association between the mean values of udder surface samples and the parallel individual raw milk samples. Staphylococcus simulans was mostly identified species among other coagulase-negative staphylococcal species identified by molecular sequencing. A higher coagulase-negative staphylococcal count of bulk tank milk than individual raw milk shows possible contamination during milking and storage. Therefore, further studies are required to investigate the other sources of bulk tank milk contamination to improve the hygienic quality of milk in the studied farms.

\section{ACKNOWLEDGEMENTS}

This work was supported by the EFOP-3.6.3VEKOP-16-2017-00008 project and it is co-financed by the European Union and the European Social Fund. The authors acknowledge the contribution of Dr. Rita Sipos (Biomi Ltd. Company, Hungary) in the $16 \mathrm{~S}$ rRNA sequencing analysis. 


\section{REFERENCES}

Bergonier, D.-Berthelot, X. (2003): New advances in epizootiology and control of ewe mastitis. Livestock Production Science. 79: $1-16$.

Bytyqi, H.-Mehmeti, H.-Vehapi, I.-Rrustemaj, F-Mehmeti, I. (2013): Effect of bacterial content and somatic cell count on sheep milk quality in Kosovo. Food Science and Nutrition. 4: 414-419.

Contreras, A.-Sierra, D.-Sanchez, A.-Corrales, J.C.-Marco, J.G.Paape, M.G.-Gonzalo, C. (2007): Mastitis in small ruminants. Small Ruminant Research. 68: 145-153.

European Commission (EC) (2005): Regulation (EC) No. 2073/2005 of the Commission of the European Communities of November 2005, microbiological criteria for foodstuffs. The Official Journal of the European Union. L338: 1-26.

Gelasakis, A.I.-Mavrogianni, V.S.-Petridis, I.G.-Vasileiou, N.G.C.Fthenakis, G.C. (2015): Mastitis in sheep-the last 10 years and the future of research. Veterinary Microbiology. 185: 136-146.

Gonzalo, C.-Carriedo, J.A.-García-Jimeno, M.C.-Pérez-Bilbao, M.-de la Fuente, L.F. (2010): Factors influencing variation of bulk milk antibiotic residue occurrence, somatic cell count, and total bacterial count in dairy sheep flocks. Journal of Dairy Science. 93: 1587-1595.

Kadariya, J.-Smith, T.C.-Thapaliya, D. (2014): Staphylococcus aureus and staphylococcal food-borne disease: an ongoing challenge in public health. BioMed Research International. 2014: 827965.

Lane, D.J. (1991): 16S/23S rRNA sequencing In: Stackebrandt, E. and Goodfellow, M. (ed.), Nucleic Acid Techniques in Bacteria Systematics. John Wiley and Sons Ltd., London. 115-147.

Martins, B.K.-Faccioli, Y.P.-Bonesso, F.M.-Fernandes, S.Oliveira, A.A.-Dantas, A.-Zafalon, F.L.-Cunha, S.R. (2017): Characteristics of resistance and virulence factors in different species of coagulase-negative staphylococci isolated from milk of healthy sheep and animals with subclinical mastitis. Journal of Dairy Science. 100: 2184-2195.

Mavrogianni, V.S.-Cripps, P.J.-Fthenakis, G.C. (2007): Bacterial flora and risk of infection of the ovine teat duct and mammary gland throughout lactation. Preventive Veterinary Medicine. 79: 163-173.

Onni, T.-Sanna, G.-Cubeddu, G.P.-Marogna, G.-Lollai, S.-Leori, G.-Tola, S. (2010): Identification of coagulase-negative staphylococci isolated from ovine milk samples by PCR-RFLP of $16 \mathrm{~S}$ rRNA and gap genes. Veterinary Microbiology. 144: $347-352$.
Podkowik, M.-Park, J.Y.-Seo, K.S.-Bystroń, J.-Bania, J. (2013): Enterotoxigenic potential of coagulase-negative staphylococci. International Journal of Food Microbiology. 163: 34-40.

Poveda, J.M.-Jiménez, L.-Perea, J.M.-Arias, R.-Palop, M.L. (2020): Farming practices influence antibiotic resistance and biogenic amine capacity of staphylococci from bulk tank ewe's milk. Animals. 10: 1622.

Spanu, C.-Berger, Y.M.-Thomas, D.L.-Ruegg, P.L. (2011): Impact of intramammary antimicrobial dry treatment and teat sanitation on somatic cell count and intramammary infection in dairy ewes. Small Ruminant Research. 97: 139-145.

Tonamo, A.-Komlósi, I.-Varga, L.-Czeglédi, L.-Peles, F. (2020): Bacteriological quality of raw ovine milk from different sheep farms. Animals. 10: 1163.

Ünal, N.-Çinar, O.D. (2012): Detection of staphylococcal enterotoxin, methicillin-resistant and Panton-Valentine leukocidin genes in coagulase-negative staphylococci isolated from cows and ewes with subclinical mastitis. Tropical Animal Health and Production. 44: 369-375.

Vasileiou, N.G.-Cripps, P.J.-Ioannidi, K.-S.-Chatzopoulos, D.C.Gougoulis, D.A.-Sarrou, S.-Orfanou, D.C.-Politis, A.P.-Calvo Gonzalez-Valerio, T.-Argyros, S.-Mavrogianni, V.S.-Petinaki, E.-Fthenakis, G.C. (2018): Extensive countrywide field investigation of subclinical mastitis in sheep in Greece. Journal of Dairy Science. 101: 7297-7310.

Vasileiou, N.G.-Chatzopoulos, D.C.-Sarrou, S.-Fragkou, I.A.Katsafadou, A.I.-Mavrogianni, V.S.-Petinaki, E.-Fthenakis, G.C. (2019): Role of staphylococci in mastitis in sheep. Journal of Dairy Research. 86: 254-266.

Yoon, S.H.-Ha, S.M.-Kwon, S.-Lim, J.-Kim, Y.-Seo, H.-Chun, J. (2017): Introducing EzBioCloud: a taxonomically united database of $16 \mathrm{~S}$ rRNA gene sequences and whole-genome assemblies. International Journal of Systematic and Evolutionary Microbiology. 67: 1613-1617.

Zell, C.-Resch, M.-Rosenstein, R.-Albrecht, T.-Hertel, C.-Götz, F. (2008): Characterization of toxin production of coagulasenegative staphylococci isolated from food and starter cultures. International Journal of Food Microbiology. 127: 246-251. 
